\title{
Perancangan Game Berbasis Multimedia Development Life Cycle (MDLC) Tentang Tokoh Pahlawan Indonesia Masa Kini untuk Generasi Z
}

\author{
Puji Rahmah Shalih ${ }^{1}$, Irfansyah ${ }^{2}$ \\ 1,2) Program Studi Desain Komunikasi Visual, Fakultas Seni Rupa dan Desain, \\ Institut Teknologi Bandung \\ Jl. Ganesha No.10, Lb. Siliwangi, Kecamatan Coblong, Kota Bandung, Jawa Barat 40132 \\ Email: ujirahma@gmail.com, fandkv@yahoo.co.id
}

\begin{abstract}
ABSTRAK
Indonesia sudah mengalami masa penjajahan oleh negara lain sampai akhirnya bisa memerdekakan diri. Prosesnya tidak luput dari perjuangan banyak orang yang terlibat dari berbagai pihak yang berperang dengan negara penjajah. Orang-orang tersebut dinamakan pahlawan yang sudah berjasa bagi Indonesia. Berbagai generasi sudah terlewati seiring dengan berjalannya waktu. Dengan munculnya teori generasi, generasi saat ini bisa kita sebut sebagai generasi $\mathrm{Z}$ atau generasi yang tumbuh dekat dengan teknologi. Di era teknologi yang dekat dan bebas ini, generasi ini tetaplah memerlukan sosok panutan atau pahlawan namun para pahlawan zaman dulu tentu saja sudah tidak sesuai lagi dengan zaman sekarang, zaman dulu pahlawan masih menggunakan senjata dan berperang secara fisik, berbagai masalah baru pun muncul salah satunya adalah kasus intoleransi dan radikalisme. Game merupakan salah satu media yang popular, game tidak hanya berfungsi sebagai hiburan tetapi bahan informasi, melatih beberapa aspek dan pembelajaran. Game akan dibuat menggunakan metode MDLC (Multimedia Development Life Cycle) metode ini terdiri dari enam tahapan yaitu concept, design, material collecting, assembly, testing dan distribution. Hasilnya didapatkan tokoh panutan, karir, karakteristik dan kontribusi dari tokoh-tokoh di Indonesia saat ini dan beberapa merupakan sesuatu yang baru kemudian akan dibungkus dalam sebuah game yang berisi karakteristik kepahlawanan di zaman generasi $\mathrm{Z}$.
\end{abstract}

Kata kunci: Game, Generasi Z, MDLC, Pahlawan Indonesia, Pahlawan Indonesia Masa Kini

\begin{abstract}
Indonesia has experienced a period of colonialism by other countries until finally it can free itself. The process did not escape the struggle of many people involved from various parties who fought with the colonial state. These people are called heroes who have contributed to Indonesia. Various generations have passed over time. With the emergence of generation theory, the current generation we can call generation $Z$ or the generation that grows close to technology. In the era of technology that is near and free, this generation still needs role models or heroes, but the heroes of the past are certainly no longer compatible with today, in the past, heroes still used weapons and fought physically, new problems arose, one of which emerged. is a case of intolerance and radicalism. Games are one of the popular media, games do not only function as entertainment but are information material, training in several aspects and learning. The game will be made using the MDLC (Multimedia Development Life Cycle) method. This method consists of six stages, namely concept, design, material collecting, assembly, testing and distribution. The results obtained role models, careers, characteristics and contributions of figures in Indonesia today and some are something that will then be wrapped in a game that contains the characteristics of heroism in the $Z$ generation.
\end{abstract}

Keywords: Games, Generation Z, Indonesian Heroes, Indonesian Heroes Today, MDLC

\subsection{Latar belakang}

\section{Pendahuluan}

Sudah bepuluh-puluh tahun lamanya sejak kemerdekaan Indonesia, perkembangan teknologi menjadi sangat pesat, menciptakan berbagai generasi yang berbeda sampai sekarang, hal ini membuat munculnya berbagai hal baru, berbagai penyelesaian dan permasalahan yang berbeda dari sebelumnya, salah satunya adalah pahlawan pada zaman kemerdekaan akan menjadi sesuatu hal yang berbeda dibandingkan dengan pahlawan yang ada dalam pikiran generasi yang baru. 
Menurut artikel dalam koran Pikiran Rakyat (pikiran-rakyat.com), Indonesia membutuhkan banyak tokoh pahlawan masa kini untuk menghadapi ancaman terbesar bagi kedaulatan bangsa salah satunya adalah intoleransi dan radikalisme. Bambang Soesyanto, sebagai Ketua MPR RI dalam artikel online Pikiran Rakyat (2019) [1] menyatakan "Saat ini perjuangan yang kita lakukan bukan lagi mengangkat bambu runcing ataupun senjata. Ancaman nyata saat ini adalah masalah intoleransi dan radikalisme. Tugas kita bersama untuk menjaga keutuhan NKRI". Menurut CNN Indonesia (2019) [2] kasus intoleransi telah mencapai 31 kasus dalam setahun dan menurut situs berita Liputan 6 terdapat lebih dari 100 kasus radikalisme dalam beberapa tahun terakhir dilihat dari tag radikalisme dalam search engine Liputan 6 (2020). Selain itu, dengan merajalelanya media sosial muncul istilah hoaks, menurut KBBI hoaks adalah informasi palsu yang biasanya dibuat dengan tujuan yang jahat. "Menjadi pahlawan masa kini dapat dilakukan oleh siapa pun warga negara Indonesia dalam bentuk aksi-aksi nyata memperkuat keutuhan NKRI salah satunya adalah tidak menyebarkan berita hoax" menurut Juliari P. Batubara, Menteri Sosial RI (2019) [3] dari bernasnews.com. Ditambah lagi dengan banyaknya tokoh-tokoh baru influencer di media sosial dan tidak semuanya melakukan tindakan positif, ada juga yang melakukan tindakan negatif yang bisa disebut sebagai mencari sensasi untuk popularitas. Berdasarkan hal tersebut tentunya profil dan ciri khas pahlawan masa kini perlu diketahui oleh semua orang, terutama generasi Z.

Sejak munculnya teori generasi, kita diperkenalkan oleh generasi X, Y dan Z. Generasi Z adalah generasi teknologi. Mereka telah melayari internet dan website seiring dengan usia mereka sejak mereka masih belum bercakap. Generasi $\mathrm{Z}$ telah dibimbing dan digalakkan oleh kedua orang tuanya menggunakan dunia media sosial sejak kecil. Media game dipilih tidak hanya dipakai untuk bermain tetapi juga untuk pembelajaran. Menurut Agnes, Nadia dan Tanzil (2015) [4] dalam jurnal pembuatan Game Android Kebudayaan Indonesia ICCSI mengatakan bahwa game adalah obat dari kebosanan, pengembangan otak, penyelesaian masalah, peningkatan konsentrasi, melatih kecepatan, dsb. Dalam pembuatannya, game sendiri mempunyai bermacam-macam jenis yang disebut dengan genre, genre akan dibuat menyesuaikan dengan tujuan penggunaan game dan akan dibuat dengan menggunakan banyak genre game didalamnya penulis membuat tesis yang berjudul Perancangan Game berbasis Multimedia Development Life Cycle tentang Tokoh Pahlawan Indonesia Masa Kini untuk Generasi Z.

\subsection{Tinjauan literatur singkat}

\subsubsection{Game}

Menurut Agustinus Nilwan (1996) [5] game diartikan sebagai suatu aktifitas terstruktur atau juga digunakan sebagai alat pembelajaran. Game dapat dikarakteristikan dari apa pemain lakukan misalnya : (1) peralatan; (2) peraturan; (3) skill, strategi dan keberuntungan; (4) pemain satu atau lebih dari satu. Berdasarakan jenis platform yang digunakan, yaitu : (1) arcade games; (2) PC games; (3) console games; (4) handheld games; (5) mobile games.

Menurut Fullerton (2008) [6], struktur game terdiri dari dua bagian yaitu elemen- elemen formal (formal elements) dan elemen-elemen dramatis (dramatic elements) . Elemen-elemen formal terdiri atas (1) pemain, (2) objektif, (3) prosedur, (4) aturan, (5) sumber daya, (6) konflik, (7) batasan, (8) hasil. Sedangkan elemenelemen dramatis terdiri atas (1) tantangan, (2) bermain, (3) premis, (4) karakter, (5) cerita, (6) membangun dunia, (7) bagian dramatis.

\subsubsection{Generasi $Z$}

Menurut Yanuar (2016) [7] generasi $\mathrm{Z}$ adalah generasi paling muda yang baru memasuki angkatan kerja, disebut juga iGeneration atau generasi internet. Generasi $\mathrm{Z}$ memiliki kesamaan dengan generasi $\mathrm{Y}$, tapi generasi Z mampu mengaplikasikan semua kegiatan dalam satu waktu (multi tasking) seperti: menjalankan sosial media menggunakan ponsel, browsing menggunakan PC, dan mendengarkan musik, menggunakan headset. Apapun yang dilakukan kebanyakan berhubungan dengan dunia maya. Sejak kecil generasi ini sudah mengenal teknologi dan akrab dengan gadget canggih yang secara tidak langsung berpengaruh terhadap kepribadian.

\subsubsection{Pahlawan Indonesia}

Menurut Undang-Undang nomor 20 tahun 2009[8], pahlawan adalah gelar yang diberikan kepada warga negara Indonesia atau seseorang yang berjuang melawan penjajahan di wilayah yang sekarang menjadi wilayah Negara Kesatuan Republik Indonesia yang gugur atau meninggal dunia demi membela bangsa dan negara, atau yang semasa hidupnya melakukan tindakan kepahlawanan atau menghasilkan prestasi dan karya yang luar biasa bagi pembangunan dan kemajuan bangsa dan negara Republik Indonesia. 


\subsection{Alasan diadakan penelitian ini}

Penelitian ini diadakan untuk mencari tahu karakteristik pahlawan seperti apa yang dicari oleh generasi Z, mencari profil seperti tokoh, karir, sifat dan kontribusi apa yang muncul dari tokoh yang dicari oleh generasi Z.

\subsection{Pertanyaan tujuan.}

1. Bagaimana profil tokoh dan peran pahlawan Indonesia masa kini di kalangan Generasi Z?

2. Bagaimana merancang game berbasis MDLC tentang profil tokoh dan peran pahlawan Indonesia masa kini bagi Generasi Z?

\section{Metode Penelitian}

Perancangan game ini akan menggunakan metode Multimedia Develompent Life Cycle (MDLC). Metode MDLC adalah metode yang digunakan Sutopo dengan memodifikasi metode dari Luther. Dalam Munir (2012) [9] metodologi pengembangan multimedia ini terdiri dari 6 tahapan, yaitu concept, design, material collecting, assembly, testing dan distribution adapun digambarkan seperti di bawah ini :

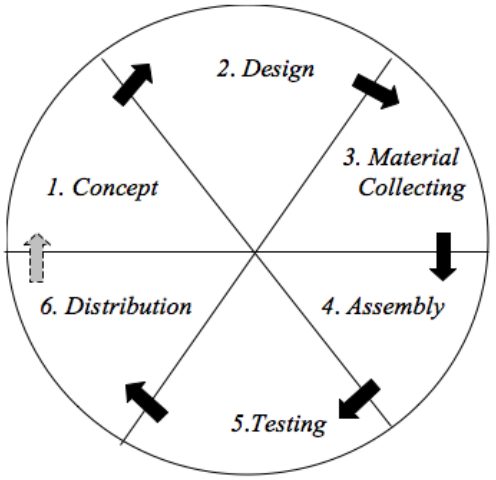

\subsection{Concept}

Gambar 1. MDLC

Tahap concept (konsep) adalah tahap untuk menentukan tujuan dan siapa pengguna program (identifikasi audience). Selain itu menentukan macam aplikasi (presentasi, interaktif, dll) dan tujuan aplikasi (hiburan, pelatihan, pembelajaran, dll).

\subsection{Design}

Design (perancangan) adalah tahap membuat spesifikasi mengenai arsitektur program, gaya, tampilan dan kebutuhan material/bahan untuk program.

\subsection{Material Collecting}

Material Collecting adalah tahap dimana pengumpulan bahan yang sesuai dengan kebutuhan dilakukan. Tahap ini dapat dikerjakan paralel dengan tahap assembly.

\subsection{Assembly}

Tahap assembly (pembuatan) adalah tahap dimana semua objek atau bahan multimedia dibuat. Pembuatan aplikasi didasarkan pada tahap design.

\subsection{Testing}

Dilakukan setelah selesai tahap pembuatan (assembly) dengan menjalankan aplikasi/program dan dilihat apakah ada kesalahan atau tidak pada tahap ini terdapat pengujian game dengan instrumen valid yang sudah dipersiapkan. 


\subsection{Distribution}

Pada tahap ini, aplikasi akan disimpan dalam suatu media penyimpanan. Jika media penyimpanan tidak cukup untuk menampung aplikasinya, kompresi terhadap aplikasi tersebut akan dilakukan. Tahap ini juga dapat disebut tahap evaluasi untuk pengembangan produk yang sudah jadi supaya menjadi lebih baik. Hasil evaluasi ini dapat digunakan sebagai masukan untuk tahap concept pada produk selanjutnya.

\section{Hasil dan Pembahasan}

Seiring dengan berjalannya waktu, maka pahlawan di masa kemerdekaan akan berbeda dengan pahlawan di masa kini, Yusuf Kalla dalam Tribunnews.com (2018) [10] menyatakan bahwa ada perbedaan cukup mendasar mengartikan pahlawan masa lalu dengan masa kini. Ia menyebutkan, jika di masa lalu makna kepahlawanan berarti angkat senjata, mengusir penjajah, dan bangsa Indonesia merdeka. Berbeda kini, yang disebut pahlawan adalah orang yang dapat memajukan bangsa. "Kepahlawanan hari ini tentu berbeda dengan masa lalu. Kepahlawan masa lalu adalah membebaskan bangsa ini dari penjajahan, kepahlawanan pada dewasa ini adalah memajukan bangsa ini, meningkatkan kecerdasan pendidikan, meningkatkan kemakmuran, meningkatkan keadilan, itulah pahlawan dewasa ini."Yusuf Kalla (2018).

\subsection{Hasil Observasi}

Observasi dilakukan kepada beberapa generasi Z yang ada di kota dan kabupaten Bandung. Observasi dilakukan di kabupaten sebanyak 32 siswa dan di kota sebanyak 31 siswa dengan total sebanyak 63 siswa, observasi dilakukan kepada siswa kelas 10 SMA (pertengahan usia dari generasi Z), usia diambil berdasarkan survey data sekunder APJII (2018)[11] \& MMA (2019)[12], kedua survey tersebut mengatakan bahwa usia terbanyak pengguna internet dan game adalah di usia 15-24 tahun.

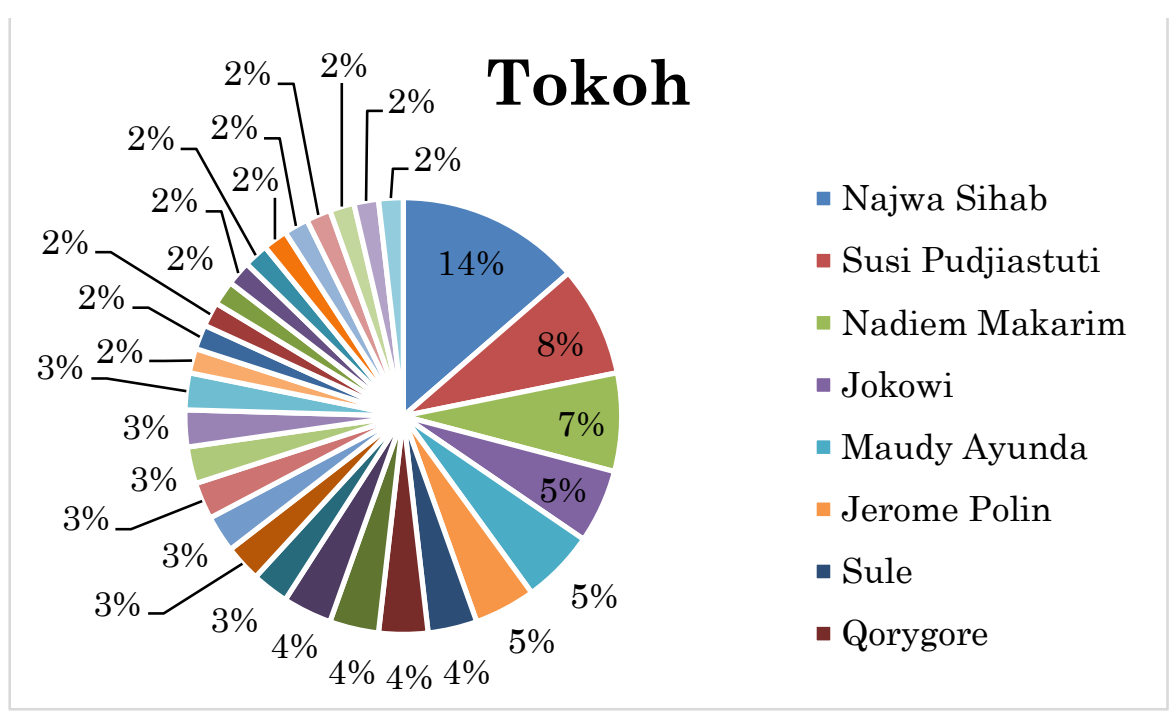

Gambar 2. Tokoh panutan hasil observasi

Berdasarkan data diatas, Najwa Sihab merupakan tokoh yang paling banyak disebutkan, diikuti oleh tokohtokoh inspiratif Susi Pudjiastuti, Nadiem Makarim dan Jokowi, setelah itu adalah tokoh-tokoh deretan entertainment seperti aktor, aktris dan penyanyi kemudian diikuti oleh youtuber/selebgram. 


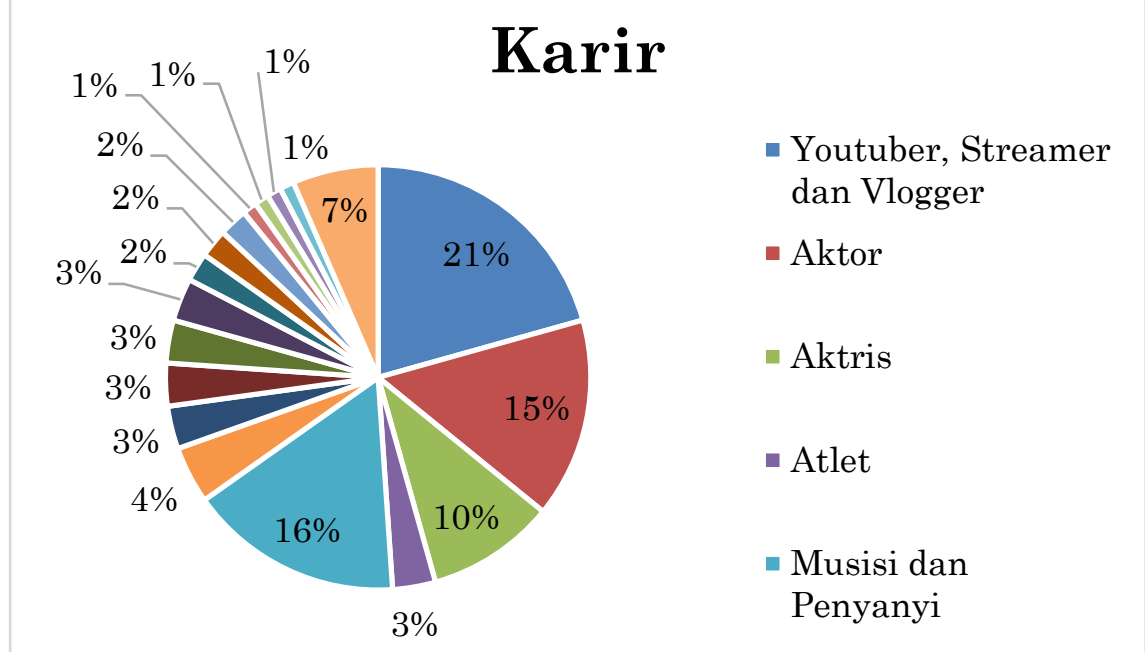

Gambar 3. Karir hasil observasi

Berdasarkan data diatas, Youtuber, Streamer dan Vlogger merupakan pekerjaan yang banyak melekat dari tokoh-tokoh yang disebutkan dalam grafik diatas. Pekerjaan ini merupakan pekerjaan baru di era milenial dan generasi $\mathrm{Z}$, pekerjaan ini mengedepankan hiburan untuk penontonnya.

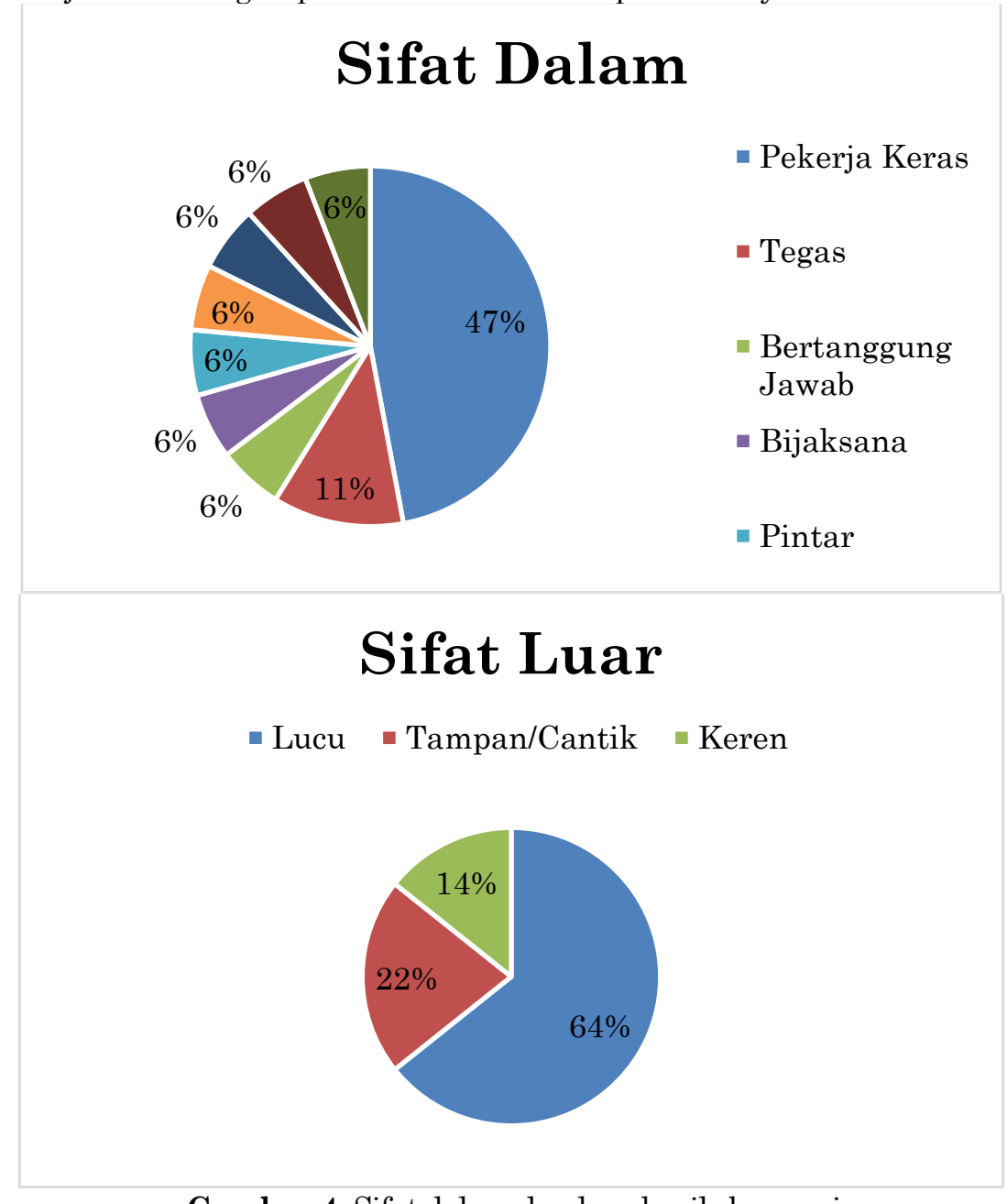

Gambar 4. Sifat dalam dan luar hasil observasi

Berdasarkan data diatas terdapat dua sifat yang melekat dari tokoh-tokoh yang responden pilih. Sifat dalam yang terbanyak disebutkan adalah pekerja keras dan sisanya seimbang antara bijaksana, setia, tegas, baik hati dsb. Sifat luar yang terbanyak adalah lucu, yang dimaksudkan lucu disini adalah membuat tawa dan sisanya adalah penampilan seperti cantik/tampan dan keren. 


\section{Kontribusi}

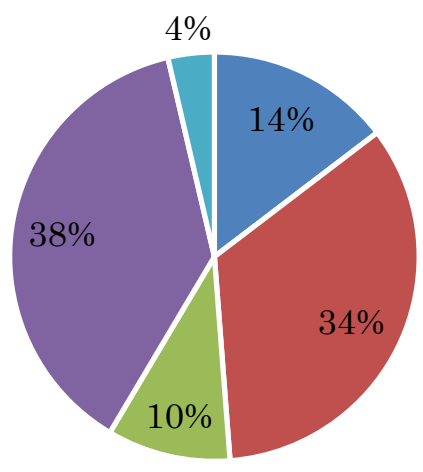

- Prestasi di dalam dan luar negeri

- Prestasi di dalam negeri

- Hiburan rakyat di layar kaca

- Content creator bermanfaat

- Atlit dalam negeri

Gambar 5. Kontribusi hasil observasi

Berdasarkan data diatas, kontribusi yang paling banyak melekat adalah pembuatan konten dalam dunia maya yang bermanfaat, isi konten tersebut bermacam-macam sesuai dengan hobi mereka dan sebagian ada yang ditonton oleh penonton luar negeri, selanjutnya kebanyakan tokoh-tokoh yang disebutkan hampir mempunyai penghargaan baik di dalam ataupun luar negeri sesuai dengan bidang mereka masing-masing, memperkenalkan Indonesia pada dunia luar. Isi penghargaan dan prestasinya beragam tetapi hal tersebut tetaplah mengharumkan nama baik Indonesia.

\subsection{Rancangan Desain}

Perancangan game akan didasarkan kepada gabungan metode MDLC dan hasil observasi, Multimedia Development Life Cycle (MDLC) adalah metode yang diambil dari Luther oleh Sutopo untuk merancang suatu multimedia. MDLC ini memiliki 6 tahapan yaitu konsep (concept), perancangan (design), pengumpulan bahan (material collecting), pembuatan (assembly), pengujian (testing) dan penyaluran (distribution).

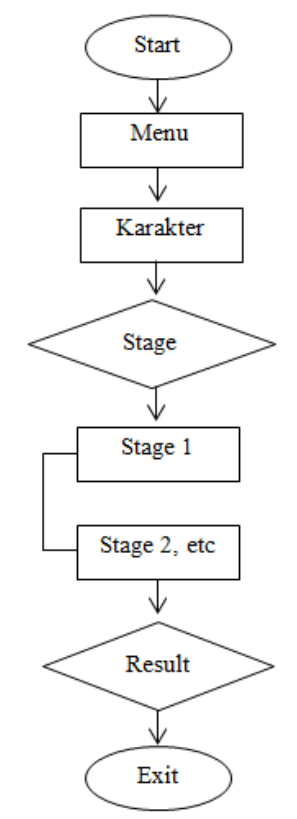

Gambar 6. Flowchart

Stage dalam game akan terbagi menyesuaikan dengan hasil observasi dan akan dibagi dalam garis besar karir, sifat, kontribusi dan tokonya, profil kesimpulan mengenai pahlawan Indonesia Generasi Z ditulis sebagai berikut : 
Tabel 1. Profil pahlawan generasi $Z$

\begin{tabular}{|c|c|c|c|}
\hline Karir & Sifat & Kontribusi & Tokoh \\
\hline Content Creator & $\begin{array}{l}\text { Pekerja Keras } \\
\text { Do It Yourself } \\
\text { (Mandiri) } \\
\text { Kreatif } \\
\text { Lucu }\end{array}$ & $\begin{array}{l}\text { Membuat content di } \\
\text { sosial media atau internet } \\
\text { dalam bidang beragam } \\
\text { seperti makanan, game } \\
\text { dan skincare }\end{array}$ & $\begin{array}{l}\text { Ria SW, Ria Ricis, } \\
\text { Jess No Limit, Tanboy } \\
\text { Kun Adzillanie Idzati, } \\
\text { dsb }\end{array}$ \\
\hline Aktor/Aktris & $\begin{array}{l}\text { Pintar } \\
\text { Baik Hati } \\
\text { Rendah Hati } \\
\text { Cantik/Tampan } \\
\text { Lucu }\end{array}$ & $\begin{array}{l}\text { Public Figure Masyarakat } \\
\text { Berprestasi di kancah } \\
\text { dalam dan luar negeri }\end{array}$ & $\begin{array}{l}\text { Reza Rahardian, Iko } \\
\text { Uwais, Maudy } \\
\text { Ayunda, Dian } \\
\text { Sastrowardoyo, Deni } \\
\text { Cagur, dsb. }\end{array}$ \\
\hline Musisi/Penyanyi & $\begin{array}{l}\text { Pekerja Keras } \\
\text { Baik Hati } \\
\text { Cantik/Tampan } \\
\text { Lucu }\end{array}$ & $\begin{array}{l}\text { Public Figure Masyarakat } \\
\text { Berprestasi di kancah } \\
\text { dalam dan luar negeri }\end{array}$ & $\begin{array}{l}\text { Afgan Syahreza, } \\
\text { Pamela Safitri, } \\
\text { Marion Jola, Ardhito } \\
\text { Pramono, dsb. }\end{array}$ \\
\hline Menteri & $\begin{array}{l}\text { Tegas } \\
\text { Pintar } \\
\text { Bijaksana } \\
\text { Rendah Hati } \\
\text { Sederhana }\end{array}$ & $\begin{array}{l}\text { Public Figure Masyarakat } \\
\text { Pengatur berbagai macam } \\
\text { aspek dan bidang di } \\
\text { Indonesia } \\
\text { Berprestasi di berbagai } \\
\text { bidang kancah dalam dan } \\
\text { luar negeri }\end{array}$ & $\begin{array}{l}\text { Susi Pudjiastuti, } \\
\text { Nadiem Makarim, Sri } \\
\text { Mulyani, Wishnutama }\end{array}$ \\
\hline
\end{tabular}

\section{THE MODERN HEROES}

START

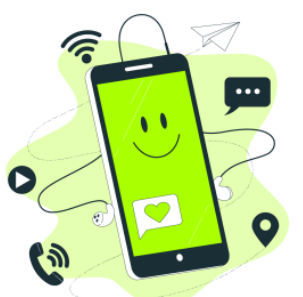

SIAPA NAMAMU?

Anonymous

KARIR APA YANG KAMU PiLIH?

Content Creator $\nabla$

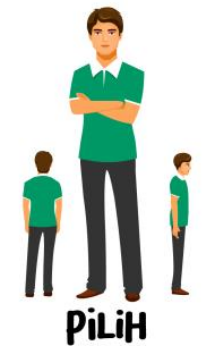

PiliH
PiLiHKARAKTER:

Ayo kita mulai bereksplorasi dengan karaktermu
dan mulai menjadi seorang content creatorl

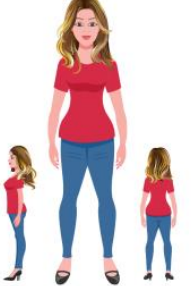

PiLiH

Gambar 7. Visual pembukaan game 


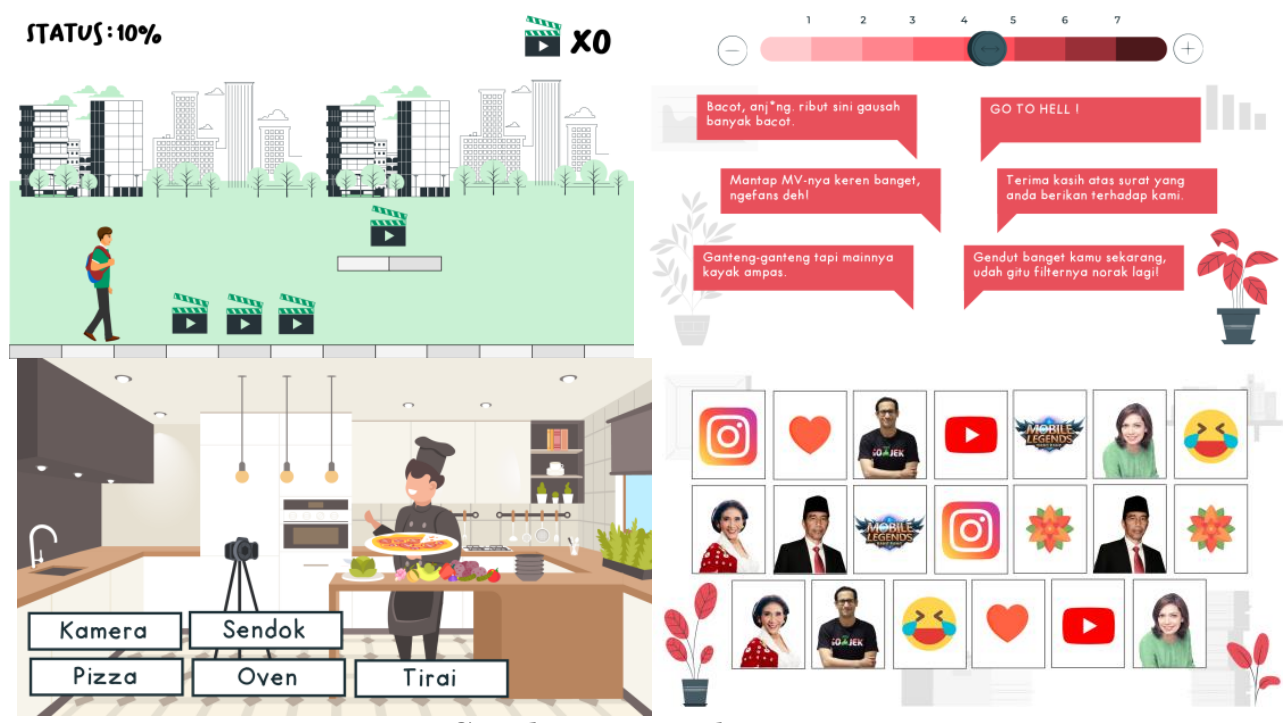

Gambar 8. Visual isi game

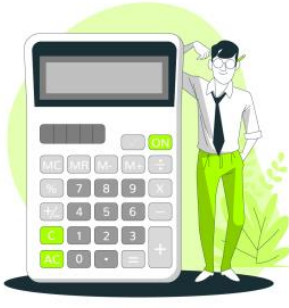

KAMU BERHAJiL!

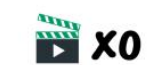

CHAPTER 1. [SELESAi]

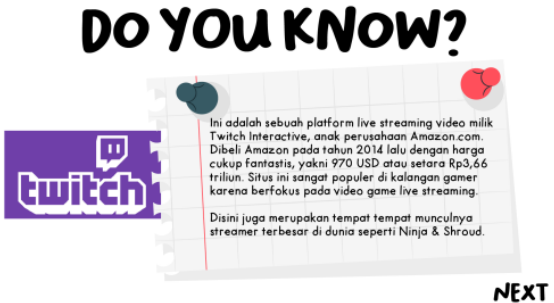

NEXT

NEXT

\section{ACHIEVEMENT}

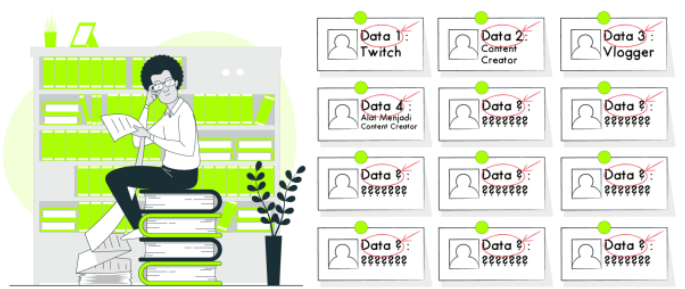

Gambar 8. Visual reward game

\section{Simpulan}

Dalam penelitian ini didapatkan bahwa kebanyakan generasi $\mathrm{Z}$ memilih tokoh pahlawan yang mereka dapatkan dari media internet. Tokoh yang mereka pilih pada era ini kebanyakan merupakan tokoh yang keluar dari media internet seperti Youtube dan Instagram. Hal tersebut mengakibatkan karir baru seperti content creator menjadi suatu pekerjaan yang menjanjikan. Bidang yang tokoh tersebut tekuni juga berbeda beda, salah satunya adalah makanan, game atau skincare. Mereka juga senang kepada tokoh yang menghibur dan lucu dibandingkan melihat dari penampilan. Game dibuat berdasarkan hasil observasi tersebut, salah satu stagenya akan berfokus kepada karir content creator salah satunya adalah dimana para pemain mendapatkan banyak istilah seperti menghapus konten yang tidak pantas. Diharapkan game ini bisa menjawab tokoh tokoh apa saja yang disukai dan dijadikan panutan oleh generasi $\mathrm{Z}$, serta membantu generasi $\mathrm{Z}$ untuk mendapatkan informasi dan selektif dalam memilih tokoh-tokoh yang sesuai untuk mereka. 


\section{Ucapan Terima Kasih}

Terima kasih kepada Dr Irfansyah, M.Ds selaku pembimbing yang sudah membimbing penulis dalam membantu menyelesaikan penelitian ini sampai selesai, terima kasih juga kepada Institut Teknologi Bandung yang sudah memberikan bantuan sarana dan prasarana kepada penulis.

\section{Daftar Pustaka}

1. Pikiran Rakyat, 2019. Indonesia Butuh Banyak Pahlawan Masa Kini Hadapi Radikalisme [Online] (Updated 11 Nov 2019).

Tersedia di : https://www.pikiran-rakyat.com/nasional/pr-01322765/indonesia-butuh-banyakpahlawan-masa-kini-hadapi-radikalisme [Accessed 5 Feb 2020]

2. CNN Indonesia, 2019. Indonesia Butuh Banyak Pahlawan Masa Kini Hadapi Radikalism Imparsial Temukan 31 Kasus Intoleransi selama Setahun [Online] (Updated 17 Nov 2019).

Tersedia di :https://www.cnnindonesia.com/nasional/ 20191117163821-32-449096/imparsialtemukan-31-kasus-intoleransi-selama-setahun [Accessed 5 Feb 2020]

3. Bernasnews, 2019. Pahlawan Masa Kini Tidak Menyebarkan Berita Hoax dan Provokasi [Online] (Updated 10 Nov 2019).

Tersedia di : https://bernasnews.com/pahlawan-masa-kini-tidak-menyebarkan-berita-hoax-danprovokasi/ [Accessed 5 Feb 2020]

4. Kurniati, A., Nadia, Tanzil, F., \& Purnomo, F., 2015. Game Development "Tales of Mamochi" With Role Playing Game Concept Based on Android. International Conference on Computer Science and Computational Intelligence (ICCSCI 2015), pp.392-399.

5. Agustinus Nilwan, 1998. Pemrograman Animasi dan Game Profesional 4. Jakarta: Elex Media Computindo.

6. Fullerton, Tracy. 2008. Game Design Workshop. 2nd edition. USA: Elsevier

7. Yanuar Surya Putra, Theoritical Review : Teori Perbedaan Generasi, Among Makarti Vol.9 no.18 Desember 2016

8. UUD 1945

9. Munir. 2015. Multimedia Konsep dan Aplikasi dalam Pendidikan. Bandung: Alfabeta.

10. Tribunnews, 2018. Arti Pahlawan Masa Kini Ala JK [Online] (Updated 10 Nov 2018).

Tersedia di : https://www.tribunnews.com/nasional/ 2018/11/10/arti-pahlawan-masa-kini-ala-jk [Accessed 5 Feb 2020].

11. https://datareportal.com/reports/digital-2019-indonesia 
Rahmah, et al / Edsence Vol. 2 No. 2, Desember 2020 pp. 83-92 